\title{
PERAN PEKERJA SOSIAL DALAM PENANGANAN ANAK AUTIS
}

\author{
Dessy Hasanah S., A ${ }^{1}$, Meilanny Budiarti S. ${ }^{2}$, Yessi Rachmasari ${ }^{3}$. \\ dessyhasanenoch@gmail.com,meilannybudiarti13@gmail.com,yessirachma19@gmail.com
}

\begin{abstract}
ABSTRAK
Autisme adalah salah satu kelainan psikologis dan perkembangan yang dialami oleh anak. Perkembangan yang dimaksud bukan secara fisik namun lebih kepada kemampuan untuk berkomunikasi, bersosialisasi sekaligus perilaku. Gejala autis yang sangat menonjol adalah sikap anak yang cenderung tidak mempedulikan lingkungan dan orang-orang di sekitarnya, seolah menolak berkomunikasi dan berinteraksi, serta seakan hidup dalam dunianya sendiri. Penanganan yang intensif dan terpadu untuk anak autis disesuaikan dengan kebutuhan anak agar pelaksanaanya dapat memberikan hasil yang maksimal. Suatu layanan yang diberikan bagi anak autis harus disesuaikan dengan metode yang tepat sehingga dapat di terapkan secara langsung. Upaya untuk menyikapi permasalahan tersebut. Sehingga, dibutuhkan penanganan untuk anak autis yaitu peran dari professional yang terlibat. Dalam penanganan anak autis dibutuhkan profesi yang memiliki keterampilan dan pengetahuan di bidangnya. Salah satunya yaitu peran dari pekerja sosial dan profesi lainnya yang berkolaborasi dengan pekerja sosial, Pekerja sosial dalam upaya penanganan anak autis dapat melakukan assessment dan intervensi terhadap permasalahan anak autis tersebut dengan menggunakan pendekatan secara holistic dengan lingkungan sosialnya dan dengan pendekatan biopsikosial. Peran pekerja sosial juga bersama-sama dengan keluarga anak autis tersebut dapat memberikan dukungan sosial dan memotivasi anak dengan gangguan autis tersebut.
\end{abstract}

Kata kunci: Anak autis, penanganan anak autis, peran pekerja sosial

\begin{abstract}
Autism is one of the psychological and developmental disorders experienced by children. The development is not physical, but rather the ability to communicate, socialize well as behavior. Symptoms of autism that really stood out was the attitude of children who tend not to care about the environment and the people around him, as if refusing to communicate and interact, as well as living in his own world. Handling intensive and integrated for children with autism tailored to the needs of children so that implementation can provide maximum results. A service provided for children with autism should be tailored to the exact method that can be applied directly. Efforts to address these problems. Thus, needed treatment for children with autism is the role of the professionals involved. In the treatment of autistic children who have the necessary professional skills and knowledge in the field. One of them is the role of social workers and other professionals who collaborate with social workers, social workers in handling children with autism can do an assessment and intervention for children with autism are problems with using a holistic approach with the social environment and the biopsikosial approach. The role of social workers also together with families of children with autism can provide social support and motivate the children with autistic disorder.
\end{abstract}

Keywords: Children with autism, treatment of autistic children, the role of social workers

\section{PENDAHULUAN}

Setiap makhluk hidup selalu
mengalami proses pertumbuhan dan perkembangan. Dalam proses pertumbuhan dan perkembangan anak kadangkala mengalami gangguan baik sebelum proses kelahiran maupun setelah proses kelahiran. Dalam diri seorang anak yang normal, perkembangan usia mental anak dan perkembangan fisik anak sama dengan usia kronologinya. Gangguan perkembangan yang terjadi pada anak sangat beragam. Salah satu gangguan perkembangan yang saat ini cukup menjadi perhatian utama adalah autisme. Menurut DSM-IV (Diagnostic Statisctical Manual, Edisi ke-4, dikembangkan oleh American Psychiatric Associaton) dalam Theo Peeters, 2009, autisme memiliki gangguan pada retardasi mental dan perkembangan fisik. Jumlah anak Indonesia yang menyandang Autis terus bertambah, meskipun penyebabnya masih misterius, tetapi hingga kini kalangan medis di Indonesia tidak punya standar penanganan bakunya. Anak-anak yang 
mengalami gangguan autistik makin bertambah dari tahun ke tahun. Sepuluh tahun kemudian angka itu berubah menjadi satu anak penyandang autis per 500 kelahiran. Berdasarkan data Badan Pusat Statistik jumlah anak usia 5 hingga 19 tahun di Indonesia mencapai 66.000.805 jiwa, maka diperkirakan terdapat lebih dari 112.000 anak penyandang autis di Indonesia (Tempo, 2013). Berdasarkan data dari Badan Penelitian Statistik (BPS) sejak 2010 dengan perkiraan hingga 2016, terdapat sekira 140 ribu anak di bawah usia 17 tahun menyandang autisme.

Pada dasarnya tidak ada seorang pun yang ingin dilahirkan ke muka bumi ini dalam keadaan cacat atau tidak sempurna baik fisik maupun mental. Mereka pada dasarnya tidak menginginkan adanya gangguan mental ataupun gangguan kelemahan mental, realitasnya bahwa autis itu dapat terjadi pada semua kelompok masyarakat, kaya miskin, berpendidikan atau tidak, serta pada kelompok maupun etnis dan budaya. Autis, bukan sekedar kelemahan mental tetapi gangguan perkembangan mental, sehingga penderita mengalami kelambanan dalam kemampuan, perkembangan fisik dan psikisnya pun tidak mengikuti tempo perkembangan yang normal.

Beberapa permasalahan yang secara umum terdapat pada anak dengan gangguan autis adalah pada aspek sosial dan komunikasi yang sangat kurang atau lambat serta perilaku yang repetitif atau pengulangan dan keadaan ini dapat kita amati pada anak seperti kekurang mampuan anak untuk menjalin interaksi sosial yang timbal balik secara baik dan memadai, kurang kontak mata, ekspresi wajah yang kurang ceria atau hidup serta gerak-gerik anggota tubuh yang kurang tertuju, tidak dapat bermain dengan teman sebaya sehingga terlihat sendiri saja atau cenderung menjadi penyendiri bahkan tidak dapat berempati atau merasakan apa yang dirasakan orang lain.

Mengingat jumlah penyandang autis terus meningkat maka perlu adanya perhatian khusus. Penanganan yang intensif dan terpadu disesuaikan dengan kebutuhan anak agar pelaksanaanya dapat memberikan hasil yang maksimal. Suatu layanan yang diberikan bagi anak autis harus disesuaikan dengan metode yang tepat sehingga dapat di terapkan secara langsung.

Keadaan anak-anak yang mengalami gangguan autis saat ini dimasyarakat kelompok menengah kebawah sangat memprihatinkan. Selain itu fenomena saat ini banyak orang tua yang memiliki anak yang mengalami gangguan autis namun terkadang tidak menyadari bahwa anaknya mengalami gangguan autis.

Kondisi autis tersebut juga dialami oleh seorang anak laki-laki yang mengidap autis di warga Dusun IV Desa Sukadamai, Kecamatan Natar, Kabupaten Lampung Selatan, yang terpaksa di pasung oleh orangtuanya. Anak laki-laki tersebut terpaksa dipasung karena kerap menggigit kedua tangannya apabila tidak dipasung. Anak laki-laki tersebut sering lari-lari ke hutan belantara yang berada di belakang rumahnya. Selain itu, ia suka bermain di sungai dan kubangan yang berisi air kotor. Hal tersebut yang menyebabkan orangtuanya memasung anaknya sendiri. (Sumber: http://ruanghati.com/2009/10/18/kisah -tragis-anak-semata-wayangdipasung-di-kandang-/)

Dalam hal ini, perlu dilakukan upaya untuk menyikapi permasalahan tersebut. Sehingga, dibutuhkan peran dari professional yang terlibat, salah satunya yaitu peran dari pekerja sosial dan profesi lainnya yang berkolaborasi dengan pekerja sosial, Pekerja sosial dapat melakukan assessment dan intervensi terhadap permasalahan anak autis tersebut dengan menggunakan pendekatan secara holistic dengan lingkungan sosialnya.

Berdasarkan uraian diatas, penulis menyadari akan pentingnya keterlibatan peran pekerja sosial terhadap anak autis dikaji lebih dalam karena keterlibatan pekerja sosial dalam mengintervensi klien dapat membantu dalam keberfungsian sosial dan perkembangan pada lingkungan sosialnya. Selain itu, peran pekerja 
sosial juga bersama-sama dengan keluarga anak autis tersebut dapat memberikan dukungan sosial dan memotivasi anak dengan gangguan autis tersebut. Pekerja sosial bukan hanya melihat dari sudut kelemahan atau kekurangan yang ada pada diri klien tetapi juga pekerja sosial melihat dari potensi yang dimiliki oleh klien.

\section{TINJAUAN PUSTAKA}

Autisme berasal dari kata "autos" yang berarti segala sesuatu yang mengarah pada diri sendiri. Dalam kamus psikologi umum (1982), autisme berarti preokupasi terhadap pikiran dan khayalan sendiri atau dengan kata lain lebih banyak berorientasi kepada pikiran subyektifnya sendiri daripada melihat kenyataan atau realita kehidupan sehari-hari. Oleh karena itu penderita autisme sering disebut orang yang hidup di "alamnya" sendiri.

Autisme atau autisme infantil (Early Infantile Autism) pertama kali dikemukakan oleh Dr. Leo Kanner 1943 (dalam Budiman, 1998) seorang psikiatris Amerika. Istilah autisme dipergunakan untuk menunjukkan suatu gejala psikosis pada anak-anak yang unik dan menonjol yang sering disebut Sindrom Kanner. Ciri yang menonjol pada sindrom Kanner antara lain ekspresi wajah yang kosong seolah-olah sedang melamun, kehilangan pikiran dan sulit sekali bagi orang lain untuk menarik perhatian mereka atau mengajak mereka berkomunikasi.

Pada awalnya istilah "autisme" diambilnya dari gangguan schizophrenia, dimana Bleuer memakai autisme ini untuk menggambarkan perilaku pasien skizofrenia yang menarik diri dari dunia luar dan menciptakan dunia fantasinya sendiri. Namun ada perbedaan yang jelas antara penyebab dari autisme pada penderita skizofrenia dengan penyandang autisme infantile. Pada skizofrenia, autisme disebabkan dampak area gangguan jiwa yang didalamnya terkandung halusinasi dan delusi yang berlangsung minimal selama 1 bulan, sedangkan pada anakanak dengan autisme infantile terdapat kegagalan dalam perkembangan yang tergolong dalam kriteria Gangguan Pervasif dengan kehidupan autistik yang tidak disertai dengan halusinasi dan delusi (DSM IV, 1995).

Penyebab autis sangat kompleks, yang telah diketahui sekarang adalah adanya gangguan fungsi paada saraf otak. The Centers for Disease Control and Prevention(CDC) menemukan bahwa prevalensi Spektrum Autis adalah 6,6 per 1000 anak di Amerika (Rice, 2007).Berdasarkan CDC, Autism Spectrum Disorder(ASD) lebih banyak diderita oleh pria dibandingkan wanita dengan rasio 4.3 : 1 (Rice, 2007). Autis dapat terjadi pada seluruh kelas sosial dan kelompok etnis.

Peneliti menyatakan bahwa ASDs terjadi karena faktor genetik (Mamberg \& Vaeth, 2006).Tidak ada hubungan terkait dengan psikologis dan pengaruh sosial termasuk cara orang tua mendidik. Walaupun $50 \%$ orang tua meyakini bahwa ASDs terjadi karena vaksinasi, Institute of Medicine (2004) telah memastikan bahwa tidak ada hubungan timbal balik antara vaksinasi dan Autis. Jadi, ASD memiliki beberapa penyebab diantaranya:

1) Kondisi genetik

2) Infeksi virus (seperti Congenital rubella, tipe mental retardasi yang disebabkan oleh infeksi pada masa di dalam kandungan)

3) Kondisi metabolis (ketidaknormalan sintetis Purin, asam amino yang menyebabkan berbagai reaksi fisik)

4) Sindrom anomali bawaan — sejak lahir (seperti William's Syndrome).

Bagaimanapun juga, penelitian menunjukkan bahwa penurunan fungsi otak pada Autis menyebabkan kesulitan berkomunikasi dan berbahasa.

Adapun klasifikasi autisme menurut ICD (International Classification of Diseases) dan DSM - IV APA (American Psychiatric Association) adalah:

1) Chilhood autism (autisme masa kanakkanak), yaitu gangguan perkembangan yang gejalanya tampak sebelum anak mencapai usia 3 tahun. Ciri-ciri gangguan autisme masa kanak-kanak: 1) Komunikasi, antara lain: 
Perkembangan bicara terlambat, Bahasa stereotip (diulang-ulang). 2) Interaksi sosial, 3) Perilaku

2) Pervasive developmental disorder not otherwise specified (PDD-NOS), yaitu gangguan autis yang tidak umum dan terdapat ketidakmampuan pada beberapa perilaku. Ciri-ciri PDD-NOS, yaitu: Masih dapat bertatap mata, Ekspresi fascial tidak terlalu datar, Masih bisa diajak bergurau.

3) Rett's Syndrome, yaitu gangguan perkembangan yang hanya dialami oleh anak wanita. Ciri- ciri sindrom rett, yaitu: Kehamilan, kelahiran normal dan lingkar kepala normal saat lahir, Perkembangan mengalami kemunduran pada usia 6 bulan, Pertumbuhan kepala berkurang pada usia 5 bulan -4 tahun, Gerakan yang terarah hilang dan disertai dengan gangguan komunikasi serta penarikan diri secara sosial.

4) Childhoom disintegrative disorder (gangguan disintegratif masa kanakkanak), yaitu gangguan perkembangan yang sangat baik selama beberapa tahun sebelum terjadi kemunduran yang hebat. Ciri-ciri CDD, yaitu: Bicara mendadak berhenti, Mulai menarik diri, Perilaku stereotip

5) Asperger Syndrome (AS), yaitu gangguan perkembangan yang dialami pada masa anak-anak dan lebih banyak terdapat pada anak laki-laki daripada wanita. Ciri-ciri AS, yaitu: Mengalami gangguan dalam komunikasi, interaksi sosial perilaku, Pandai bicara tetapi agak terlambat, Komunikasi hanya berjalan searah, Memiliki otak yang cerdas dan daya ingat yang kuat, Memiliki sifat yang kaku dan sulit dalam belajar bersosialisasi. (Sugiyanto, 2008).

Untuk menegaskan sebuah diagnosa bahwa seorang anak mengidap autisme, ada beberapa kriteria yang harus dipenuhi. Selama ini panduan yang dipakai oleh para dokter, psikiater, psikolog biasanya merajuk pada ICD-10 (International Classification of Diseases), atau yang mengunakan rumusan dalam DSM-IV (Diagnostic Statistical Manual) yang disusun oleh kelompok Psikiatri Amerika Serikat sebagai panduan untuk menegaskan diagnosa. Pada dasarnya diagnosa autisme yang ditegakkan berdasarkan ICD-10 atau DSM-IV menunjukan kriteria yang sama. Orang tua sebenarnya dapat mencoba mengecek sendiri apakah anaknya termasuk kategori autis atau tidak dengan memperhatikan kriteria autisme yang ada di dalam DSM-IV. Beberapa kriteria seperti:

1) Aspek interaksi sosial

a. Tidak mampu menjalani interaksi sosial yang memadai, seperti kontak mata sangat kurang hidup, ekspresi muka kurang hidup, ekspresi mata kurang hidup, dan gerak-geriknya kurang tertuju.

b. Tidak dapat bermain dengan teman sebaya

2) Aspek Komunikasi

a. Sering menggunakan bahasa yang aneh dan berulang-ulang

b. Jika bicara, biasanya tidak dipakai untuk berkomunikasi

3) Aspek perilaku

a. Terpaku pada satu kegiatan yang ritualistik atau rutinitas yang tidak ada gunanya

b. Seringkali sangat terpukau pada benda.

Autis dicirikan dengan perkembangan abnormal dalam interaksi sosial yang ditandai dengan perilaku seperti mengayun-ayunkan badan, berjinjit, mengepalkan tangan, dan berputar-putar. Menurut DSM-IV, 10-40\% Autis menunjukkan perilaku khusus, terlepas dari sistem diagnosa. Meskipun perbedaan ditunjukkan oleh masing-masing individu, gangguan dalam pergaulan sosial melandasi dan menggambarkan kondisinya (Volkmar, Chwarska, \& Klin, 2005), termasuk kurangnya kepekaan terhadap orang lain, kesulitan dalam mengekspresikan emosi, dan ketidakmampuan 
untuk bermain secara sosial dan simbolik.Seiring dengan pertumbuhan semasa kanak-kanak, ketidakmampuan berinteraksi tetap berlaku terindikasi dari kesulitan berteman dan kesulitan menunjukkan empati.

Autis sering pula menunjukkan hal-hal tidak biasa seperti bersikeras dalam pembicaraan dan mengabaikan orang lain. Faktanya, Autis kesulitan untuk memahami bahasa.Dengan demikian, separuh dari populasi Autis tidak mengalami perkembangan dalam berbicara (Peliosa \& Lund, 2001).Bagaimanapun juga, banyak dari mereka yang memiliki ingatan yang kuat, kemampuan melihat dan spasial yang baik, dan memperhatikan hal-hal kecil.

\section{METODE}

Artikel ini disusun dengan menggunakan kajian literatur dan dokumen, yaitu literatur barupa buku-buku, makalah ataupun jenis tulisan lainnya dan juga kajian terhadap berbagai macam dokumen yang terkait dengan topik peran pekerja sosial terhadap penanganan anak autis yang diangkat dalam artikel ini.

\section{PEMBAHASAN}

Autisme memiliki cakupan yang luas dan bervariasi pada setiap anak. Mulai gejala paling ringan hingga terberat, dari tingkat inteligen rendah sampai di atas rata-rata. Sehingga penanganan gangguan autisme ini memerlukan beberapa pendekatan dan metode yang dilakukan secara sinergi. Autisme adalah gangguan perkembangan yang memengaruhi cara seseorang untuk berkomunikasi dengan orang lain. Membuat mereka sulit mengerti perasaan orang lain. Pada dasarnyaautisme dapat dikurangi, bahkan dihilangkan sehingga anak bisa bergaul dengan normal. Jika anak autis terlambat atau bahkan tidak dilakukan intervensi dengan segera, maka gejala autis bisa menjadi semakin parah, bahkan tidak tertanggulangi.

Pada bagian pembahasan ini, kasus yang dialami oleh seorang anak laki-laki yang menderita autis hingga dipasung oleh orangtuanya seharusnya tidak dilakukan oleh orangtua tersebut. Gangguan anak autis yaitu terdiri dari gangguan komunikasi, interaksi dan perilaku. Jika perilaku bermasalah maka dua aspek interaksi sosial dan komunikasi akan mengalami kesulitan dalam berkembang. Sebaliknya bila kemampuan komunikasi dan bahasa anak tidak berkembang, maka anak akan kesulitan dalam mengembangkan perilaku dan interaksi sosial yang bermakna.

Dalam kasus ini diketahui bahwa seorang anak-laki yang mengalami autis bersikap terlalu aktif atau hiperaktif. Selain itu, anak tersebut menunjukkan perilaku yang mungkin tidak biasa dilakukan oleh anak seusianya seperti menggigit kedua tangannya dan sering bermain di air yang kotor. Perilaku tersebut dilakukan berulang-ulang. Gangguan dalam berinteraksi juga ditunjukkan bahwa ia hanya fokus dengan dirinya sendiri tanpa memperhatikan lingkungan sekitar. Tak hanya hal itu saja, anak ini juga mengalami gangguan dalam berkomunikasi terhadap orang sekitarnya yaitu tidak dapat berbicara seperti layaknya orang normal dan lamban saat berbicara.

Selain itu, permasalahan pola perilaku, komunikasi, dan interaksi yang dialami oleh anak autis. Disisi lain, terdapat akses yang terbatas sehingga meyebabkan sulitnya orangtua dalam berkonsultasi terkait gangguan autis yang dialami oleh anaknya tersebut. Dalam menyikapi permasalahan yang ada memang seharusnya pemerintah daerah setempat dapat lebih cepat tanggap untuk merujuk ke pelayanan kesehatan maupun sosial agar dapat diberikan penanganan yang sesuai agar kasus pemasungan terhadap anak autis tidak terjadi.

Pekerja sosial dapat mengintervensi penderita ASD dan keluarganya melalui pelayanan langsung seperti menjadi administrator program, analis perilaku dan pemimpin tim. Asesmen pada ASD cukup menantang karena tidak ada tes biokimia yang bisa mendiagnosa mereka. Inti asesmen pada ASD sebagai berikut (Johnson \& Myers, 2007): 
1) Informasi dari orang tua mengenai masa kehamilan, sejarah keluarga yang pernah mengidap gangguan mental, gejala-gejala di sekitar lingkungan sosial, respon anak saat menerima pendidikan dan saat bertingkah laku.

2) Observasi langsung ke sekolah dan rumah ASD untuk mengidentifikasi interaksinya dengan teman sekelompok, orang tua, dan saudara kandung.

3) Evaluasi medis mengenai masalah sensori, pengelihatan, dan pendengaran.

4) Asesmen kognitif untuk mengetahui fungsi intelektualnya.

5) Asesmen mengenai peningkatan keterampilan sosial

6) Asesmen bahasa dan pembicaraan.

Berkaitan dengan kasus ini, pekerja sosial yang merupakan profesi dalam membantu individu dalam mencapai keberfungsian sosialnya. Peran pekerja sosial dalam kasus ini yaitu dapat menjadi manajer kasus dalam membantu anak dengan autism. Ada peran penting dan kebutuhan nyata bagi pekerja sosial yang dapat menjembatani sistem yang berbeda untuk membantu meningkatkan kualitas keseluruhan keberfungsian sosial pada anak autis tersebut. Pekerja sosial juga dapat melakukan assessment terlebih dahulu terhadap anak autis tersebut, yang bukan hanya melihat sisi permasalahan atau kekurangannya saja tetapi juga melihat kekuatan dan potensi yang dimiliki anak autis tersebut. Assessment tersebut dapat membantu untuk pengembangan langkah perawatan selanjutnya. Selain assessment individual, keterampilan sosial lain yang akan membantu pekerja sosial di bidang ini adalah kasus pengalaman manajemen dan sebagai penghubung dengan profesional lain di bidang kesehatan lainnya seperti; psikolog, psikiater maupun dokter.

Pekerja sosial juga bersama-sama dengan orang tuanya dan keluarganya memberikan dukungan kepada anak autis tersebut. Dukungan keluarga mengacu pada dukungan-dukungan sosial yang dipandang oleh anggota keluarga sebagai suatu yang dapat diakses untuk keluarga. Bentuk dukungan yang diberikan oleh keluarga adalah dorongan semangat maupun motivasi terhadap anak. Selain itu, Intervensi difokuskan pada meningkatkan kemampuan bahasa dan komunikasi, self-help dan perilaku sosial dan mengurangi perilaku yang tidak dikehendaki seperti melukai diri sendiri dengan penekanan pada peningkatan fungsi individu dan bukan "menyembuhkan" dalam arti mengembalikan penyandang autis ke posisi normal. Hal ini dilakukan untuk membantu perkembangan kognitif, bahasa dan sosial yang normal serta mengurangi perilaku stereotype dengan meningkatkan interaksi penyandang autis dengan orang lain dan tidak membiarkannya "hidup sendiri". Interaksi yang kurang justru akan menyebabkan munculnya perilakuperilaku yang tidak dikehendaki.

\section{SIMPULAN}

Autisme merupakan gangguan perkembangan masa anak yang jumlahnya semakin meningkat saat ini. Namun hal ini tidak berarti anak yang menderita gangguan perkembangan lainnya seperti lambat bicara, sangat aktif dan kurang konsentrasi. Untuk itu diperlukan pemeriksaan yang terpadu dari berbagai ahli agar diagnosa gangguan dini tepat. Diagnosa yang tepat akan intervensi yang tepat. Pekerja sosial mempunyai peran dalam manajer kasus, penghubung dengan professional lain, memberikan dukungan sosial terhadap anak autis bersama dengan keluarga dan lingkungan sekitarnya dengan menggunakan pendekatan holistic dan biopsikososial. Intervensi yang dilakukan oleh pekerja sosial untuk meningkatkan kemampuan bahasa dan komunikasi, self-help dan perilaku sosial dan mengurangi perilaku yang tidak dikehendaki seperti melukai diri sendiri dengan penekanan pada peningkatan fungsi individu dan bukan "menyembuhkan" secara total dalam arti mengembalikan penyandang autis ke posisi normal. 


\section{DAFTAR PUSTAKA}

American Psychiatric Association (APA). (2000) Diagnostic and Statistical Manual of Mental Disorders Fourth Edition Text Revision, DSM-IV-TR. Arlington, VA: American Psychiatric Association.

Nakita. Majalah. Menangani Anak Autis. PT. Gramedia .Jakarta 2002.

Sleeuwen V. Lieke. AUTISME. Petunjuk Untuk Orangtua, Guru dan Psikolog diIndonesia. Yogyakarta 1996.

Smith, Ellen. 2011. "Autism" dalam Hiller dan Gitterman (Eds.) Mental Health and Social Problems: A Social Work Perspective. London: Routledge

Sugiyanto. 2008.Perkembangan dan Belajar Motorik. Jakarta: Universitas Terbuka

http://ruanghati.com/2009/10/18/kisah-tragisanak-semata-wayang-dipasung-dikandang-kambing/. 